\title{
STRESSORS IN THE NURSING CARE DELIVERED TO POTENTIAL ORGAN DONORS
}

\author{
Laura de Azevedo Guido ${ }^{1}$ \\ Graciele Fernanda da Costa Linch ${ }^{2}$ \\ Rafaela Andolhe 3 \\ Carmine Cony Conegatto ${ }^{4}$ \\ Carolina Codevila Tonini ${ }^{3}$
}

Guido LA, Linch GFC, Andolhe R, Conegatto CC, Tonini CC. Stressors in the nursing care delivered to potential organ donors. Rev Latino-am Enfermagem 2009 novembro-dezembro; 17(6):1023-9.

This study examines those situations that are typical to the work of the nursing team in the intensive care unit, especially those that nursing teams consider stressful and are common in intensive care units in the treatment of patients being considered as potential organ or tissue donors. It is an exploratory-descriptive study, established with a qualitative approach, conducted at an Adult Intensive Care Unit. The reports revealed the fact that organ donation leads to different situations and emotions. Regarding the perception of nursing care to the potential organ donor patient, the subjects reported they did not discriminate patients when delivering care, but recognize a certain lack of self-confidence and preparation dealing with brain death. They try to minimize the effects of stressors with physical activities, social support, spirituality, or attempt to separate work from personal life.

DESCRIPTORS: organ transplantation; intensive care units; nursing; stress

\section{FACTORES DE ESTRÉS EN LA ASISTENCIA DE ENFERMERÍA AL POTENCIAL DONADOR DE ÓRGANOS}

Esta investigación tuvo como objetivo conocer las situaciones que el equipo de enfermería identifica como factores de estrés, comunes a la actuación en unidad de terapia intensiva, especialmente en la asistencia prestada al paciente considerado potencial donador de órganos y tejidos. Se trata de estudio exploratorio, descriptivo y estructurado a partir de un abordaje cualitativo, desarrollado en una unidad de terapia intensiva para adultos. Los relatos revelaron que en el proceso de captación de órganos se encuentran diferentes situaciones $y$ emociones, en lo que se refiere a la percepción de la asistencia de enfermería al paciente potencial donador de órganos. Los sujetos relataron que asisten a ese paciente sin distinciones, sin embargo reconocían cierta inseguridad y falta de preparación tratando pacientes con muerte encefálica. Sin embargo, buscaban minimizar los factores de estrés con actividades físicas, soporte social, espiritualidad o, también, trataban de separar el trabajo de su vida personal.

DESCRIPTORES: trasplante de órganos; unidades de terapia intensiva; enfermería; estrés

\section{ESTRESSORES NA ASSISTÊNCIA DE ENFERMAGEM AO POTENCIAL DOADOR DE ÓRGÃOS}

Esta pesquisa teve como objetivo conhecer as situações que a equipe de enfermagem identifica como estressantes, comuns à atuação em unidade de terapia intensiva, sobretudo na assistência prestada ao paciente considerado potencial doador de órgãos e tecidos. Trata-se de estudo exploratório, descritivo e estruturado a partir de abordagem qualitativa, desenvolvido em unidade de terapia intensiva adulto. Os relatos revelaram que o processo de captação de órgãos remete a diferentes situações e emoções, no que se refere à percepção da assistência de enfermagem ao paciente potencial doador de órgãos. Os sujeitos relataram que assistim esse paciente sem distinções, mas reconheciam certa insegurança e despreparo em se tratando de paciente com morte encefálica. No entanto, buscavam minimizar os estressores com atividades físicas, suporte social, espiritualidade ou, ainda, tentavam separar o trabalho da sua vida pessoal.

DESCRITORES: transplante de órgãos; unidades de terapia intensiva; enfermagem; estresse

Research Group 'Trabalho, Saúde, Educação e Enfermagem', Universidade Federal de Santa Maria, Brazil:

${ }^{1}$ RN, Ph.D. in Nursing, Adjunct Professor, e-mail: lauraazevedoguido@gmail.com. ${ }^{2}$ RN, Master's Student, e-mail: gracielelinch@gmail.com. ${ }^{3}$ M.Sc. in Nursing, e-mail: rafaela_andolhe@yahoo.com.br, carolinatonini@yahoo.com.br. ${ }^{4} \mathrm{RN}$, e-mail: carminec@bol.com.br. 


\section{INTRODUCTION}

Nursing has recently been characterized as a profession in continuous development, which has reached new horizons and perspectives through professional development and technological innovation. Consequently, it promotes holistic and humanized care and also becomes a concrete and visible presence in health systems.

Several professions are considered stressful, that is, their environment contributes to workers' physical and mental fatigue, which consequently affects their performance ${ }^{(1)}$. Professionals involved with health care need to adapt technological contributions to the quality of care delivery. Hospitals stand out as environments conducive to stress, which demands awareness and the ability to adapt and overcome stress-development from professionals.

From this perspective, nurses act in their daily routine with little or no awareness of the stress they are subject to. Therefore, knowledge about the process in which stress develops is essential to appropriately coping with it, otherwise it is not resolved and might lead workers to physical and emotional exhaustion $^{(2)}$.

Identifying stressors at work corresponds to identifying an agent of change, since when possible strategies are developed to minimize the effects of stressors, nurses' routines can become more productive, less exhausting and possibly attribute more value to nurses as human beings and professionals.

There is a perceptible change in the nursing team's disposition according to their patients' conditions. When patients have severe conditions and need more intensive care with an imminent risk of death, as is the case of patients in intensive care units (ICU), the environment becomes more exhausting and requires a greater ability to adapt from professionals ${ }^{(3)}$.

The ICU is characterized as a closed unit contained in the hospital. It is influenced by the hospital itself and also presents peculiarities in its work organization and in the established relations due to the type of its patients and the severity of their conditions $^{(4)}$.

In this vein, we highlight the presence of patients in the ICU with pathologies such as traumatic brain injuries, stroke and brain tumors, which oftentimes lead to brain death (BD) and consequently require intense and specific care. When one observes the dynamics of the work process in this unit, it is apparent that ICU health professionals suffer extra pressure.

Life and death are two extremes, two opposites, two phenomena(5) with which nursing is faced every day. One always fights to maintain life, but in the case of patients with $\mathrm{BD}$, even in the face of death, nurses fight for life, which in this case is represented by the vitality of organs and tissues.

When death is considered a process, there are distinctions between clinical death (cardiac and respiratory functions cease), biological death (cellular destruction/death) and brain death (cerebral activities cease). The advancement of science has permitted us to artificially extending a body's vital functions, such as circulation and breathing, however, this advancement does not allow reversing the end of brain activity. Therefore, criteria to determine BD were defined according to standards established for transplantation, which results in much debate about the subject, in terms of both information and concepts $^{(5)}$.

The Decree no 10.211 regulates the Law no 9434/97, which in turn defines post-mortem issues related to tissue, organs and parts of the human body for transplantation. The same law designates the Resolution of the Federal Council of Medicine (CFM) no $1480 / 97$ as a source of criteria for diagnosing brain death. According to this resolution, BD is defined as total and irreversible cessation of cerebral or torso activities. Clinical neurological exams and supplementary examination charts are needed to confirm such diagnoses. In such a situation, the cardio respiratory function is maintained through the use of equipment and medication ${ }^{(6)}$.

In general, we observe that the ICU nursing team who cares for the patient with $B D$ is exposed to stress related to the characteristics of this ward and is also subject to stress related to the care demanded by this kind of patient. The nursing team's activities include direct care to the potential donor in addition to other care related to the attention required by family members and the health team in general as these individuals are also related to the need to preserve the organs and concerns with the potential recipient.

Nursing care is essential to the maintenance of the donor and the quality of organs to be donated. In keeping with this perspective, a recent study ${ }^{(7)}$ indicates that beliefs and values related to the 
maintenance care of potential donors interferes with or determines a certain detachment from patients, consequently harming care delivery. Authors stress that education is a determining factor in the success or failure of transplantation. Therefore, they suggest the incorporation of educational programs, courses, instruction and seminars as strategies to provide tools to the nursing team and consequently minimize suffering.

The care delivered to BD patients and potential donors is exhausting due to several physiological alterations, especially hemodynamic ones, which if not rapidly and effectively managed, can compromise the maintenance and donation of one or more organs.

Thus, this study examines situations common to the work of nursing teams in the ICU that they find stressful, especially the care delivered to potential organ and tissue donors.

\section{METHOD}

This exploratory and descriptive study with a qualitative approach was carried out in an adult intensive therapy unit (AICU) of a school hospital in the South of Brazil.

The study was developed with 19 members of the AICU nursing team. They were interviewed in their workplace during working hours. Data were collected through semi-structured interviews with closed questions to characterize the population, identify their satisfaction at work and preparedness for delivering care to potential organ and tissue donors. Open questions were also included asking participants about stressors common to their work in the ICU, their perception about the care delivered to potential organ donors and ways they found to minimize stress during their daily routine.

Closed questions addressed the following: age, gender, function and time at the AICU. In terms of satisfaction and preparedness for this kind of work, three answer options were previously established: satisfied/prepared, moderately satisfied/prepared, little satisfied/prepared.

Interviews were guided by the following open questions: What stressors do you identify in the ICU environment? Taking into account the BD patients and potential organ and tissue donors you have cared for in the ICU, how do you perceive the nursing care delivered to them and what do you consider particularly stressful and/or physically/emotionally exhausting? What would you do to relieve everyday stress, particularly after delivering care to BD patients?

Responses and reactions from the interviewees were noted on the interview's script itself, which permitted reading and validating these records immediately after each interview. Interviewees (nurses and technicians) were identified by the letters $E$ and $T$ respectively followed by a number in crescent order.

To organize and analyze the data obtained in interviews, the results were read and interpreted, then they were identified and grouped according to similarity between answers. These were organized by theme: stressors related to the work environment in the ICU, stressors related to the care delivered to patients with BD in the ICU and ways to minimize stressors.

Thematic analysis allows uncovering core meanings that composes the communication, whose presence or frequency, means something to the aimed analytical objective ${ }^{(8)}$. Therefore, we opted to organize the content of sequential sentences proposed by the author, which are: pre-analysis, exploration of the material, data treatment and interpretation.

The Project was submitted to and approved by the hospital's Ethics Research Committee. The participants signed free and informed consent forms.

\section{RESULTS AND DISCUSSION}

Seven nurses and 12 nursing technicians were identified among the 19 interviewees and their responses were separately analyzed to acquire a better understanding of the studied phenomenon. The rationale is that they are two distinct groups, in relation to demographic data, to aspects related to their work/perception of the care delivered to BD patients and also to potential stressors.

The group of nurses was composed of women $(100 \%)$ with an average age of 41 years and an average time working at the AICU of 8.14 years. Among technicians, $91.67 \%$ were female with average age of 35.66 years and an average time working at the unit of 4.25 years.

When asked about their satisfaction at work, the majority of nurses $(71.42 \%)$ reported to be moderately satisfied and the remainder (25.58\%) reported to be satisfied. Among technicians, 50\% 
reported to be satisfied, $41.66 \%$ moderately satisfied and $8.33 \%$ little satisfied. We observed that the professionals who reported to be little satisfied were those who had worked for the lesser amount of time in the ICU.

We point out that a study carried out with nurses from an ICU found a correlation between dissatisfaction at work and level of stress. Stress reflected on the professionals' health with cardiovascular manifestations, alterations in the digestive system or even musculoskeletal disorders ${ }^{(3)}$.

Health care institutions, their administrators and managers can positively intervene in this issue with a view to ensure better working conditions in the professional environment and, consequently, better quality of care delivery. It is believed that "if managers are able to use the power of their positive attributes and create a working environment conducive to the development of individuals, work becomes more positive and productive" ${ }^{\prime(9)}$.

Regarding the question about being prepared or not to deliver care to patients potential organs and tissue donors, most of the nurses considered themselves to be moderately prepared (71.44\%), $14.28 \%$ prepared and $14.28 \%$ little prepared. Half of the technicians reported to be prepared, $33.34 \%$ moderately prepared and $16.66 \%$ considered themselves little prepared to deal with such situation.

Because the ICU is an environment with typical characteristics, with differentiated patients and employs advanced technologies, it requires the team to constantly update itself ${ }^{(3-4)}$. Consequently, betterprepared and qualified professionals feel more secure to perform their work in this unit.

Stressors related to the work environment at the ICU

The two groups' responses converged in relation to the environment in the ICU, which noted the following as the main stressors: interpersonal relationships, lack of the equipment required to provide care, intense noise caused by alarms of devices and even by conversations and circulation of the health team. These stressors are confirmed in the following reports:

The difficult relationship with some professionals and oftentimes the involvement with interpersonal conflicts in which you kind of become the mediator... one needs to be prepared to not get involved (N8).
The lack of equipment is stressful because there are some working poorly or broken, considerably hindering our work (T2).

Intense noise, alarms going off all the time, and the circulation of many people in the unit also is noisy and is stressful (N17).

Similar data were found in a study carried out with an $\mathrm{ICU}^{(10)}$ nursing team in which interpersonal relationships coupled with lack of cooperation, deficient communication and unequal treatment of employees directly interfered in care delivery and personal satisfaction. It is believed that interpersonal relationships are difficult and stress among nurses is highlighted due to the relationships they have to maintain with other people to carry out their administrative activities ${ }^{(11)}$.

It is worth considering that if living and relating with another in the nursing work environment is something natural and necessary; especially because it involves teamwork, it is necessary that these professionals have opportunities to discuss strategies to know each other.

Another indicated stressor was the concern with the maintenance of equipment necessary to provide care to patients. These results are similar to those found among nurses of a surgical center and anesthetic recovery unit asserting, in an individual and subjective way, that activities related to care maintenance are the most stressful ones ${ }^{(2)}$.

Some authors associate stress with working conditions and consider the number of employees available for work and equipment in appropriate quantity and quality as essential to providing the best care possible ${ }^{(2,10-11)}$

Monitors, respirators, infusion pumps and others are necessary because they signal when something is not responding as expected and warn about problems ${ }^{(10)}$. However, the noise and commotion caused by professionals is not necessary, harming not only the sleep and rest of patients but also troubling other members of the team itself.

The stressor reported in the study setting can be explained by the fact it is related to a closed unit in a school hospital that sometimes includes the circulation of faculty members for courses in the health fields. There is also circulation of professionals from other areas who support the care provided to patients such as physiotherapists, radiology technicians, nutrition and pharmacy. 
Stressors in the nursing care provided to BD patients in AICUs

The use of donated organs for transplantation depends mainly on detecting brain death, on clinical care and hemodynamic maintenance of stable conditions to optimize organs and tissue, ensuring their vitality $^{(12)}$. It is worth noting that some of these care procedures are mainly nurses' responsibilities. These procedures demand attention and responsibility from nurses and also a high level of collaboration within the nursing team.

Nurses reported they provided care and did not discriminate in the treatment of potential organ and tissue donors. However, they acknowledged a certain insecurity when dealing with patients with $B D$ as shown by the following statements:

Patients with $B D$ have to be treated or cared for as normal patients, only that they require more attention and training (E3).

Appropriate care, lots of attention, just like we care for other patients (E7)

The absence of brain activity does not impede respiratory and circulation functions needing to be artificially maintained, which is what physiologists define as technical life. Knowledge about this fact is essential for the transplantation of organs of brain dead donors, because artificial maintenance of the cardiopulmonary functions during a certain period ensures the viability of tissues and organs, setting up favorable transplantation conditions ${ }^{(5)}$. Nurses are responsible for keeping donors hemodynamically stable up to the moment of sending them to the surgical center.

Nursing technicians acknowledged their lack of preparedness regarding the care to be delivered to potential donors. They were concerned with appropriate patient maintenance and the organs' vitality, with "keeping the dead body alive". This is what we observe in the following statements:

Care delivery is kind of tense; we were not prepared for these situations (T5).

Care delivery is normal, of course, only that we pay more attention so that the patient is kept in an optimal state for transplantation (T10).

Among the care procedures that a patient with brain death and potential organ and tissue donor requires, nurses note the following as the most stressful situations: interacting and orienting family members and also experiencing their reaction to brain death. Similarly, nursing technicians considered having to share the experience of family members in coping with brain death stressful, a fact that can be evidenced by the following reports of both groups:

What I considered the most stressful experience is having to share the family members' suffering, acknowledging the situation, their reactions to it and provide them care (E3).

I find that the most exhausting thing is the emotional side of family members, which shakes the professional and is very stressful for us on the nursing team (T13).

Knowing how to deal with the family is very complicated and difficult (E12).

Nurses and nursing professionals are exposed to stressors related to the critical situation to which patients, family members and the entire health team are subject. Addressing the family of a potential donor is one of the nursing team's tasks and one of the most delicate aspects to be faced by these professionals $^{(13)}$

The family members' different reactions should be taken into account: despair, crying, feelings of profound sorrow, anger and grief, beliefs that the situation can be reversed and even acknowledging the loss. Every family is based on principles, values, multiple beliefs, which often interfere in their decisions $^{(14)}$.

The family interview is one of the most complex steps, because it involves ethical, legal and emotional aspects. We stress that there is no script to be followed because each family has its own values and beliefs ${ }^{(12)}$. The nurse has to be prepared to clarify doubts and deal with different feelings and situations that might occur during interviews. This is one of the most stressful moments for these professionals.

The interview carried out with family members and to clarify and ask for organ donation after BD is confirmed, is a shocking and delicate situation for professionals. However, when there is appropriate clarification about BD, the family is able to better cope with the situation and finds it easier to think about the possibility of donation. Hence, professionals have to be prepared to provide explanations to family members, which will possibly cause them less exhaustion and might also reflect on these professionals' own professional and personal satisfaction $^{(12,14)}$

Ways to minimize stressors

Nurses physically exercised and sought support within the team to minimize tension and daily 
fatigue, in particular after delivering care to a BD patient. Nursing technicians, on the other hand, sought to cope with stress by focusing on spirituality or tried to separate work from their personal life. These behaviors can be evidenced in the following statements:

I try to turn off from this environment: what happens at work stays here. I keep on with my private life (T9).

I try to leave my work here at the hospital and not take it with me, but when it happens I try to do some leisure activity (T6).

Talking with someone about events. Doing aquatic aerobics and walking (E3).

(...) I walk, seek inner balance, talk to peers to seek support (E19).

Spirituality can reflect on individuals' health and one can adapt to stress when seeking or having religious experiences ${ }^{(15)}$. This is a possible justification to the extent spirituality positively affects coping with stress, especially among the studied nursing technicians.

Additionally, social support reported by nurses as a way to minimize stress can benefit the quality of life at work. Social support is inversely proportional to stress; it represents a protector effect that is manifested in low levels of stress. The larger the social support, both at work and in the family, the lower is the stress level ${ }^{(16)}$.

Thus, hospitals should give professionals opportunities to reflect, discuss and learn so that they improve their ability to adapt to situations that involve ethical dilemmas, focusing on experiencing exchange ${ }^{(17)}$.

\section{FINAL CONSIDERATIONS}

Organ transplantation has significantly developed in recent years due to technical and immunological advancements, especially since the

\section{REFERENCES}

1. Mauro MYC, Muzi CD, Guimarães RM, Mauro CCC. Riscos Ocupacionais em Saúde. Rev Enferm UERJ 2004 setembro; $12(3): 338-45$.

2. Guido LA. Stress e coping entre enfermeiros de Centro Cirúrgico e Recuperação Anestésica. [tese]. São Paulo (SP): Escola de Enfermagem/USP; 2003.

3. Cavalheiro AM, Moura DF Junior, Lopes AC. Estresse de enfermeiros que atuam em unidade de terapia intensiva. Rev Latino-am Enfermagem 2008 janeiro; 16(1):25-32. development of imunossupressive drugs, which have contributed to the achievement of better results and more efficient procedures that have saved many lives.

Brain death is a polemic subject but is part of a hospital'sn work organization process, especially in an ICU. In this study, the interviewees' insecurity and difficulty to formulate answers to questions about the subject revealed the importance of promoting opportunities to discuss it as well as the associated stress. This study has confirmed that stress is inherent to the care provided to potential donors and family members.

Thus, we can infer that the process of organ harvesting refers simultaneously to different situations and emotions. It refers to technical scientific knowledge, to subjectivity and to the relationship established with patients and family members, who have diverse concepts, beliefs and attitudes, all during a very brief time of high complexity.

Therefore, aspects already demonstrated in other studies ${ }^{(3,10,18)}$ related to the stress, suffering and fatigue nursing teams working in intensive care units have to cope with are confirmed. As in other studies ${ }^{(4,7,13)}$, this study reaffirms and notes difficulties and limitations these professionals experience in managing potential donors, interacting with and orienting family members. In the face of such evidence, it is expected this study will contribute to reflection and knowledge, enabling the identification of, and consequently the minimization of, stressors in ICUs.

Based on these assumptions, we believe that these subjects will open a range of possibilities for nursing interventions, especially those focused on professional improvement and on the attempt to understand human suffering, to respond to human uniqueness, acknowledging differences between individuals and respecting their inner lives.

4. Ferreira FG. Desvendando o estresse da equipe de enfermagem em terapia intensiva. [dissertação]. São Paulo (SP): Escola de Enfermagem/USP; 1998.

5. Gogliano D. Pacientes terminais: morte encefálica. Rev Dir Civ Imob Agrário-Emp 1993 janeiro; 17(63):57-85.

6. Lei n. 10.211 de 23 de março de 2001. Altera dispositivos da Lei n. 9.434, de 4 de fevereiro de 1997, que dispõe sobre a remoção de órgãos, tecidos e partes do corpo humano para fins de transplante e tratamento e dá outras providências; [citado em 09 de Março de 2009]. Disponível em: http:// dtr2001.saude.gov.br/transplantes/portaria/lei10211.htm 
7. Lemes MMDD, Bastos MAR. Os cuidados de manutenção dos potenciais doadores de órgãos: estudo etnográfico sobre a vivência da equipe de enfermagem. Rev Latino-am Enfermagem 2007 setembro/outubro; 15(5):986-91.

8. Minayo MCS. O desafio do conhecimento: pesquisa qualitativa em saúde. $8^{\circ}$ ed. São Paulo (SP): Hucitec; 2004. 9. Nelson DL, Simmons BL. Eutresse e esperança no trabalho: mapeando a jornada. In: Rosso AM, Perrewé PL, Sauter SL, organizadoras. Stress e qualidade de vida no trabalho: perspectivas atuais da saúde ocupacional. São Paulo (SP): Atlas; 2005. p. 125-38.

10. Coronetti A, Nascimento ERP, Barra DCC, Martins JJ. O estresse da equipe de enfermagem na unidade de terapia intensiva: o enfermeiro como mediador. Arq Catarinenses Med. 2006 setembro; 35(4):36-43.

11. Bianchi ERF. Enfermeiro hospitalar e o stress. Rev EsC Enferm USP 2000 junho; 34(4):390-4.

12. Guarino AJ. Stress e capacitação de órgãos - uma realidade vivenciada pelos enfermeiros [dissertação]. São Paulo (SP): Escola de Enfermagem/USP; 2005.
13. Amorim SF. Estudo sobre estresse e burnout em enfermeiros captadores de órgãos de doadores cadáveres para transplante na cidade de São Paulo [dissertação]. São Paulo (SP): Universidade Federal de São Paulo - Escola Paulista de Medicina; 2006.

14. Santos MJ, Massarollo MCKB. Processo de doação de órgãos: percepção de familiares de doadores cadáveres. Rev Latino-am Enfermagem 2005 maio; 13(3):382-7.

15. Saad M, Masiero D, Battistella LR. Espiritualidade baseada em evidências. Acta Fisiátrica 2001 dezembro; 8(3):10712.

16. Paschoal $T$, Tamayo A. Impacto dos valores laborais e da interferência família-trabalho no estresse ocupacional. Psicologia: teoria e pesquisa 2005 maio; 21(2):173-80.

17. Gutierrez BAO, Ciampone MHT. O processo de morrer e a morte no enfoque dos profissionais de enfermagem de UTIs. Rev Esc Enferm USP 2007 dezembro; 41(4):660-7.

18. Martins JT, Robazzi MLCC. O trabalho do enfermeiro em terapia intensiva: sentimentos de sofrimento. Rev Latino-am Enfermagem 2009 janeiro; 17(1):52-8. 